Article

\title{
Designing Democratic Constitutions: The Search for Optimality
}

\author{
Steffen Ganghof \\ Faculty of Economics and Social Sciences, University of Potsdam, 14482 Potsdam, Germany; \\ E-Mail: ganghof@uni-potsdam.de
}

Submitted: 17 May 2019 | Accepted: 16 September 2019 | Published: 25 November 2019

\begin{abstract}
This article analyses salient trade-offs in the design of democracy. It grounds this analysis in a distinction between two basic models of democracy: simple and complex majoritarianism. These models differ not only in their electoral and party systems, but also in the style of coalition-building. Simple majoritarianism concentrates executive power in a single majority party; complex majoritarianism envisions the formation of shifting, issue-specific coalitions among multiple parties whose programs differ across multiple conflict dimensions. The latter pattern of coalition formation is very difficult to create and sustain under pure parliamentary government. A separation of powers between executive and legislature can facilitate such a pattern, while also achieving central goals of simple majoritarianism: identifiable cabinet alternatives before the election and stable cabinets afterward. The separation of powers can thus balance simple and complex majoritarianism in ways that are unavailable under parliamentarism. The article also compares the presidential and semi-parliamentary versions of the separation of powers. It argues that the latter has important advantages, e.g., when it comes to resolving inter-branch deadlock, as it avoids the concentration of executive power in a single human being.
\end{abstract}

\section{Keywords}

electoral systems; parliamentary government; presidential government; semi-parliamentary government

Issue

This article is part of the issue "Trade-Offs in the Political Realm: How Important Are Trade-Offs in Politics?" edited by Todd Landman (University of Nottingham, UK) and Hans-Joachim Lauth (University of Wuerzburg, Germany).

(C) 2019 by the author; licensee Cogitatio (Lisbon, Portugal). This article is licensed under a Creative Commons Attribution 4.0 International License (CC BY).

\section{Introduction}

Political scientists have long analyzed the trade-offs involved in the design of democratic institutions and asked which design, if any, is best. Some have focused on electoral systems (e.g., Carey \& Hix, 2011; Shugart, 2001), others on executive formats (e.g., Cheibub, 2007; Linz, 1990) and still others on broader models or visions of democracy (e.g., Lijphart, 2012; Powell, 2000). The goal of the present article is to survey and advance this literature from a particular theoretical perspective. I re-conceptualize the core difference between different models of democracy in order to highlight the crucial importance of whether or not there is a separation of powers between the executive and the legislature.

Much of the existing literature distinguishes between "majoritarian" democracy, on the one hand, and "consensus" (Lijphart, 2012) or "proportional" democracy (Powell, 2000) on the other. In contrast, I propose a distinction between simple and complex majoritarianism (Ganghof, 2015). What it shares with the more established ones is its focus on differences in electoral and party systems: Simple majoritarianism tries to reduce the number of parties and politicized conflict dimensions; complex majoritarianism embraces multiple parties, the easy entrance of new parties and a multidimensional structure of partisan conflict. Where my conceptualization differs, however, is that it also contrasts different styles of coalition-formation. Complex majoritarianism is not about reaching consensus or the proportional influence of all parliamentary parties, but about the possibility of governing with shifting, issuespecific coalitions. Powell (2000, p. 256, note 259$)$ noted this possibility in his seminal study, but did not investigate it systematically.

If we do so, the difference between executive formats becomes much more salient. The reason is that a pattern of issue-specific coalition-making in the leg- 
islature is rather difficult to create and sustain under pure parliamentary government. Since the cabinet can be voted out of office at any time and for purely political reasons by some parliamentary majority, there is a greater imperative to build fixed, multi-party coalitions in which each party agrees to support the cabinet in return for veto power over all or most pieces of legislation (Tsebelis, 2002). In contrast, a separation of powers between executive and the legislature can facilitate the formation of issue-specific legislative coalitions.

The article also compares different variants of the separation of powers. While the political science literature tends to associate this separation closely with the notion of presidential government, I emphasize that this association is historical rather than logical. Because the invention of presidential government was strongly influenced by monarchical ideas, the justification of the separation of powers became closely linked to the justification of concentrating executive power in a single human being. However, alternatives to presidential government exist, most notably "semi-parliamentary government" (Ganghof, 2018), which can achieve the benefits of the separation of powers without the dangers of personalizing power in the executive. These benefits include the potential to achieve a particular balance between the goals of simple and complex majoritarianism.

Section 2 elaborates on the distinction between simple and complex majoritarianism. On this basis, Section 3 discusses prominent strategies for optimizing the design of parliamentary systems of government. It shows how these strategies are able to reconcile some elements of simple and complex majoritarianism but not others. Sections 4 and 5 discuss how the presidential and "semiparliamentary" variants of the separation of powers can achieve a different form of reconciliation between the two models of democracy. Section 6 discusses deadlock, one of the main dangers of the separation of powers, and suggests that it might be easier to avoid under the semiparliamentary variant. Section 7 is a brief conclusion.

\section{Simple versus Complex Majoritarianism}

The distinction between simple and complex majoritarianism builds on the seminal works of Powell (2000) and Lijphart (2012) but departs from them in important ways. I have discussed the differences in some detail elsewhere (Ganghof, 2015; Ganghof \& Eppner, 2019). Here I try to summarize the distinction succinctly.

Simple majoritarianism is similar to what Powell and Lijphart call "majoritarian democracy." The core ideal is to limit the number of parliamentary parties to only two, so that one party gains a legislative majority. I focus on three goals associated with this model of democratic majority formation. First, voters ought to be able to choose more or less directly between two alternatives for government. This is often called "identifiability". Second, one-party majority cabinets are generally seen to achieve maximal "clarity of responsibility." Third, a low number of parties in parliament and cabinet is conducive to "cabinet stability." As the name suggests, simple majoritarianism tries to simplify as much as possible-at least in the eyes of the voters - the process of democratic majority formation.

Complex majoritarianism, in contrast, embraces the complexity that results from having multiple parties competing on multiple, partly cross-cutting, political issues. Again, we can highlight three goals in particular. The first is the "mechanical proportionality" of the electoral system. This goal is often seen as an expression of citizens' democratic equality and it requires that $x$ percent of the votes of any party-real and hypothetical-is translated into x percent of seats (McGann, 2013). Mechanical proportionality also makes it easier for new parties to enter the competition. The second related goal is an "unconstrained multidimensionality" of partisan preferences. If some parties take "left" positions on some issues and "right" positions on others, more voters are likely to find a party they feel represented by. There is also some evidence to suggest that unconstrained multidimensionality is beneficial for how citizens actually perceive the quality of democracy (Reinermann \& Barbet, 2019; Rosset \& Stecker, 2019; Stecker \& Tausendpfund, 2016).

The third goal of complex majoritarianism is that coalition-building on legislation is issue-specific, so that different majorities can form on different pieces of legislation. It is with respect to this goal that the concept of complex majoritarianism differs most strongly from Lijphart's (2012) consensus democracy or Powell's (2000) proportional democracy. There is nothing inherently consensual about issue-specific decision-making, as the majority on each issue might be minimal-winning (i.e., it includes only as many parties as are needed for a majority). Similarly, issue-specific decision-making does not imply the proportional influence of all parties but might rather give disproportionate influence to the median party on the respective issues. Authors like Ward and Weale (2010; see also Weale, 2019) prefer issue-specific coalition-building for precisely this reason. Nevertheless, it is important to point out that in his seminal study, Powell was well aware of the potential attractiveness of issue-specific coalition-building and saw it as one variant of his proportional democracy. He wrote:

A third argument in favor of proportionalism is that policymakers should choose the policy desired by the citizen majority on each issue. Because many issues will be considered by the national government between every election and different sets of citizens will form the majority on different issues, it is important that the policy-making coalition not be locked into place by the immediate election outcome.....Although this is potentially an important argument for proportional approaches, it is not one that I am able to see how to explore empirically with available data. (Powell, 2000, p. 256, note 259) 
Table 1. Two polar models of democratic majority formation.

\begin{tabular}{ll}
\hline Simple Majoritarianism & Complex Majoritarianism \\
\hline Identifiability & Mechanical Proportionality \\
\hline Clarity of Responsibility & Unconstrained Multidimensionality of Representation \\
\hline Cabinet Stability & Issue-Specific Coalition-Building \\
\hline
\end{tabular}

Source: Author's.

In sum, we can characterize each of the two polar models of democratic majority formation in terms of three goals, as summarized in Table 1 . The respective goals are at odds with one another, as those of simple majoritarianism are facilitated by having few parliamentary parties, whereas those of complex majoritarianism tend to encourage or require the existence of many parties. In the next section, I will discuss how the resulting tradeoffs play out in a pure parliamentary system and to what degree influential optimization strategies can achieve a sort of compromise between the two models.

\section{Trade-Offs and Their Optimization in Parliamentary Systems}

Efforts to balance the goals of simple and complex majoritarianism are severely constrained by a parliamentary system of government, in two main ways. First, this system implies a single chain of delegation from voters to the cabinet: Voters elect a parliament, which selects a cabinet (e.g., Strøm, 2003). Due to this chain, the competing demands that the ideals of simple and complex majoritarianism put on the party system must thus be balanced in the design of the electoral system for the legislature. Second, by definition, a parliamentary system implies that the cabinet can at any time be dismissed by some parliamentary majority for purely political reasons in a no-confidence vote. As a result, the precise rules of cabinet selection and removals must balance the competing goals of cabinet stability and issue-specific majority formation. I discuss both constraints in turn.

\subsection{Optimizing the Electoral System}

There are two prominent ideas about how to optimize the design of the electoral system, which are particularly relevant for parliamentary systems of government. Both of them try to reconcile at least one of the two first goals of simple majoritarianism-identifiability and clarity of responsibility-with some degree of proportional representation. The first idea focuses on pre-electoral coalitions. If we can design the electoral system to be proportional but also to induce multiple parties to group into two competing blocs, we might be able to reconcile proportionality with identifiability (Shugart, 2001). Voters can vote for a party and, simultaneously, for one of two competing coalitions. Hence, they can be fairly represented and directly select the government, rather than leaving this to politicians in post-electoral coalition nego- tiations. Germany's mixed-member proportional system was regarded as an example for this kind of optimization, at least for some time. In the 1980s and 1990s German elections were often characterized by a competition between two pre-electoral coalitions: Christian Democrats and Liberals versus Social Democrats and Greens.

While this is a plausible path towards optimization, it can reconcile the goals of complex majoritarianism only to a rather limited extent. One reason is that two competing blocs are more likely to emerge when parties compete along one dominant conflict dimension (Ganghof, Eppner, \& Heeß, 2015). Since electoral systems with a high mechanical proportionality facilitate multiple dimensions of competition, it is probably not enough that the electoral system encourages the formation of competing pre-electoral blocs-it must also reduce the mechanical proportionality of the electoral system and constrain dimensionality. Hence these two basic goals of complex majoritarianism must be substantially compromised.

The second prominent optimization approach explicitly embraces the need for reducing mechanical proportionality. It assumes that what we should really care about is "behavioral" proportionality, that is, how proportionally actual votes are translated into seats (cf. Best \& Zhirnov, 2015): If some degree of mechanical disproportionality keeps some voters from voting for small parties, and some would-be parties or candidates to enter the competition, this is as it should be. Carey and Hix (2011) take this view and note that the trade-off between behavioral proportionality and the number of parties in parliament and government is non-linear. That is, electoral systems with a moderate degree of mechanical disproportionality might substantially reduce the number of parties in parliament and government, thereby substantially boosting clarity of responsibility, but without increasing behavioral disproportionality very much. These systems might be optimal in that there is much to gain at low costs; there is a sort of sweet spot of mechanical disproportionality. Spain is an example of a country that seemed to hit Carey and Hix's (2011) sweet spot.

Of course, the plausibility of this argument depends not only on how we feel about the importance of mechanical vis-à-vis behavioral proportionality, but also on how much non-linearity there actually is in the relationship between behavioral proportionality and party fragmentation. A number of authors worry that the potential for optimization might not be that great after all, and that our efforts at finding the sweet spot might also lead 
us to the worst of both worlds: substantial disproportionality and many parties (McGann, 2013; Raabe \& Linhart, 2018; St-Vincent, Blais, \& Pilet, 2016). In any case, the second optimization approach also accepts significant institutional constrains on the two basic goals of complex majoritarianism: mechanical proportionality and the dimensionality of party preferences.

\subsection{Optimizing Executive-Legislative Relations}

Let us now turn to the design of the precise rules for cabinet selection and removal. These matter for the trade-off between cabinet stability, on the one hand, and issue-specific majority formation in the legislature on the other. From the perspective of complex majoritarianism, single-party minority cabinets that seek issuespecific support seem attractive (Ward \& Weale, 2010; Weale, 2019). They could be quite powerful (Tsebelis, 2002, pp. 97-99) but would also have to be attentive to the preferences of potential support parties. In contrast, when parties enter fixed coalitions, either portfolio coalitions or support agreements, they tend to establish each other as "veto players," so that legislation requires unanimity within the coalition (Tsebelis, 2002). Empirical evidence suggests that when minority cabinets form, it is more likely that opposition parties can represent their voters not only in parliamentary debate but also in actual policy-making (e.g., Angelova, Bäck, Müller, \& Strobl, 2018; Ganghof, Eppner, Stecker, Heeß, \& Schukraft, 2019; Klüver \& Zubek, 2018). The problem is that institutional efforts to stabilize cabinets in fragmented parliaments may discourage the formation of minority cabinets, especially single-party minority cabinets that seek issuespecific support.

One way to stabilize cabinets in fragmented parliaments is to make it institutionally more difficult for a parliamentary majority to dismiss the cabinet. The most drastic way to do so is to require the no-confidence vote to be "constructive." This means that an (absolute) parliamentary majority can only dismiss the prime minister if it simultaneously elects a new one. The constructive no-confidence vote can be used to balance permissive electoral rules with highly restrictive rules of cabinet removal (Lijphart, 2012, p. 298). It was first implemented in Germany's Basic Law of 1949 and later also adopted, e.g., by Spain, Belgium and Israel. A constructive vote of no-confidence is likely to work against the formation of (single-party) minority cabinets without stable support in parliament, for several reasons.

One reason is institutional consistency. Since the constructive vote of no-confidence implies an investiture vote, consistency seems to require an investiture vote also after an election. Sieberer (2015) has shown that cabinet selection and removal rules are correlated in this way. Yet when the cabinet has to be voted into office by a majority in parliament, or at least when this majority must be absolute, the formation of minority cabinets becomes more difficult (Bergman, 1993; Cheibub, Martin,
\& Rasch, 2019). When simple majorities are ultimately sufficient in an investiture vote, the formation of (singleparty) minority cabinets becomes relatively easier, Spain being a case in point (Field, 2016).

However, more recent developments in Spain might also exemplify a second, more strategic reason why a constructive no-confidence vote works against the formation of (single-party) minority cabinets. Since the constructive no-confidence vote stabilizes a minority cabinet after it takes office, opposition parties might be less willing to let it take office. These parties may thus be discouraged from supporting a single party in an investiture vote (by abstaining or voting for it). This logic would help to explain the severe problem of cabinet formation after the Spanish elections in April 2019 (Field, 2019). The conditions for a single-party minority cabinet were in many ways very favorable: The Socialist Party was the largest party by some margin (holding 35.1 percent of the seats), it was the central (median) party on the dominant axes of political conflict, and it could have profited from the Spanish governments' strong institutional powers to set the agenda as well as the constructive noconfidence vote. Anticipating this institutional strength, however, the left-wing Unidas Podemos demanded inclusion into the government and was unwilling to support a Socialist minority cabinet in the investiture procedure. As a result, Spain is headed for yet another general election in November 2019.

Finally, there is the problem of legitimizing the government. We can imagine an institutional configuration in which the constructive no-confidence vote is combined with the absence of any investiture vote after an election. The problem with this combination is that it would greatly reduce the power of parliament over the cabinet (cf. Sieberer, 2015) and thus its ability to democratically authorize a cabinet. It might simply remain unclear which parliamentary party has the right to form a government. The underlying reason for this legitimacy problem is that parliamentary elections only register voters' first preferences. As a result, the plurality party-the party with the most votes or seats-is not necessarily the party that has the greatest voter support overall. It is not necessarily the party that has a legitimate claim to form a single-party minority cabinet. The formation of a fixed majority coalition is one way to create legitimacy on the basis of voters' first preferences. It is the coalition parties' ability to form a majority that creates a legitimate claim to govern. Hence, if we wanted to clearly legitimize a single cabinet party without a majority, we would have to allow voters to express more than their first preference. Yet this is difficult to do in a parliamentary system of government.

\subsection{An Empirical Visualization}

The arguments presented above imply that, within a parliamentary system of government, it is impossible to get the "best of both worlds." While some goals of simple majoritarianism can be reconciled, to a certain de- 
gree, with some goals of complex majoritarianism, the underlying tension between the two models of democratic majority formation remains. Ganghof, Eppner, and Pörschke (2018) visualize this fact in a descriptive data analysis for the period from 1995-2015, which is partially reproduced in Figure 1 . The two dimensions in the figure measure simple and complex majoritarianism respectively. Each dimension averages normalized measures of the three goals associated with each model (see Table 1). Normalization implies that one unit corresponds to one standard deviation, while the average value is zero. The detailed variable definitions are provided in the Appendix.

Figure 1 reveals a linear trade-off between the broader bundles of goals. All countries are fairly close to the estimated regression line. At one end of this line is the United Kingdom, which approximates the ideal type of simple majoritarianism. At the other end is Denmark, which exemplifies many elements of complex majoritarianism. Cases with "optimized" electoral systems such as Germany or Spain have less extreme positions and are above the trade-off line, but they cannot escape the underlying goal conflicts. In both countries the formation and stabilization of cabinets has also become more difficult after the period considered here. All in all, Figure 1 suggest that parliamentary systems can be designed to take intermediate positions on the trade-off line, but they can hardly transcend the overall trade-off structure. Can separation of power-systems do better?

\section{Presidentialism as Optimization}

The best-known version of the separation of powers is presidential government. It requires that the chief executive (the president) is elected independently from the legislature-usually in direct elections-and that he or she serves a fixed term. A legislative majority cannot remove the president in a political no-confidence procedure, but only in an impeachment procedure.

Since the elections of the executive (president) and legislature are institutionally separated, efforts at optimization can focus on designing them differently (Cheibub, 2006, 2007; Mainwaring \& Shugart, 1997; Shugart \& Carey, 1992). In particular, the legislature can be elected proportionally and without constraining the dimensionality of party competition. Legislative coalitions can form in an issue-specific manner, as the legislature is liberated from the need to maintain the executive in office. At the same time, presidential elections allow voters to make a clear choice between alternative governments (thus achieving identifiability) and the elected government is stabilized by the president's fixed terms. Moreover, if presidential elections use absolute majority rule (two-round systems), voters have a chance to make more than their first preferences count. If their preferred candidate in the first round does qualify for the runoff election, they still have a vote. The elected president can thus be clearly legitimized by an electoral majority, even if his or her party is far away from a majority in legislative

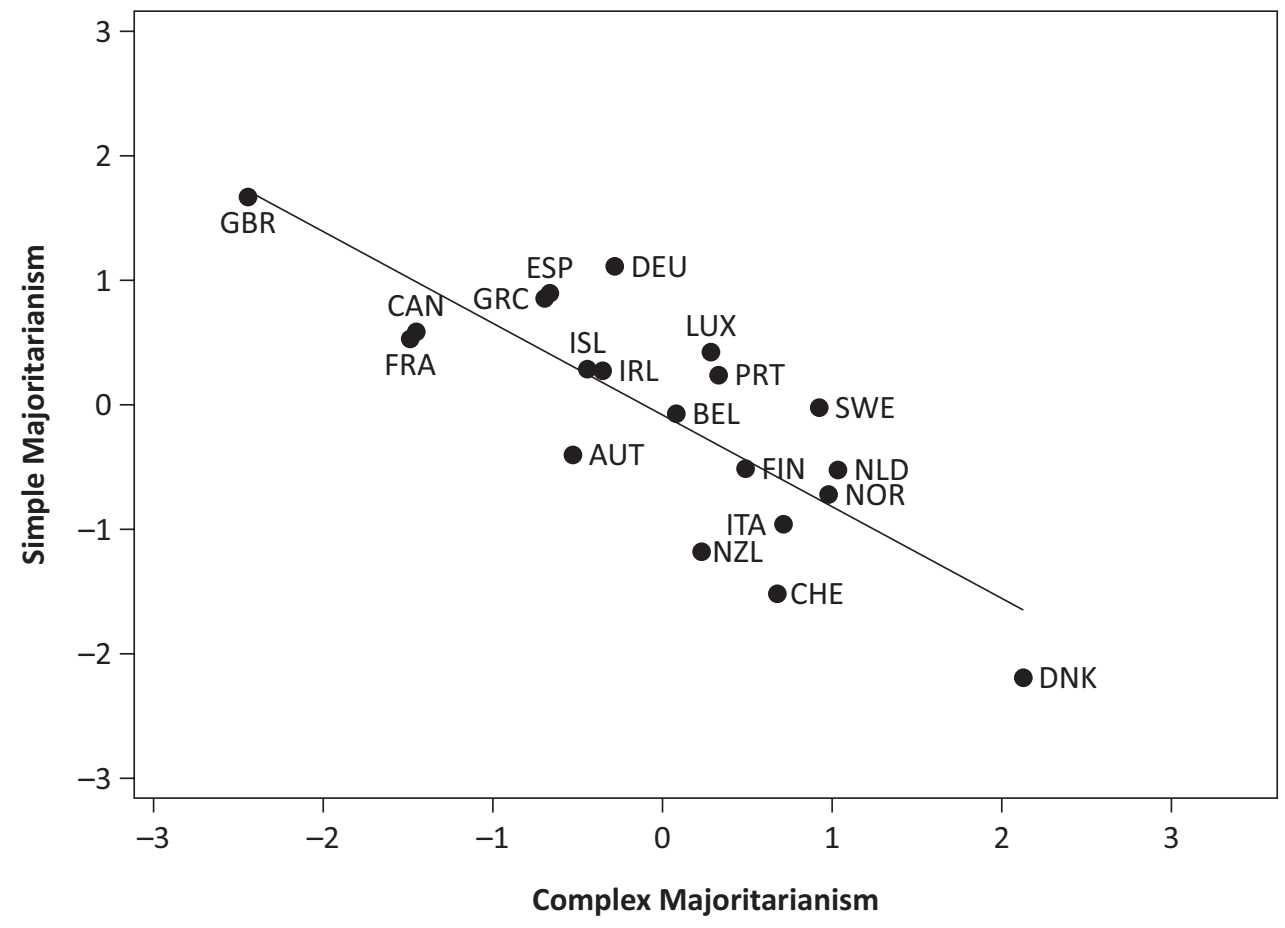

Figure 1. Trade-offs in 20 non-presidential democracies. Notes: For detailed variable definitions, see the Appendix. For data sources, see Ganghof et al. (2018, pp. 232-233). Switzerland is included as a non-parliamentary system because there is only a single chain of delegation from votes to representatives. In the semi-presidential systems, the president does not affect the values for "simple majoritarianism." Semi-parliamentary systems are excluded. Source: Adapted from Ganghof et al. (2018). 
elections. In short, the separation of powers may help to mitigate some of the relevant trade-offs. In particular, it can reconcile identifiable and stable governments with issue-specific decision-making in a multi-party and multi-dimensional legislature. In terms of Figure 1, a welldesigned presidential system could probably achieve a position in the upper right quadrant.

The separation of powers cannot optimize all tradeoffs, though. The clarity of responsibility for policies is likely to be compromised when the president's party does not have a majority in the proportionally elected assembly. After all, a minority president needs to find legislative support and thus make concessions. Clarity of responsibility might be higher if the president has strong institutional powers-agenda, veto and decree powers - so that he or she does not need to make large concessions (Cheibub, 2006). In this case, though, the proportional representation of parties in the legislature and the possibility of issue-specific legislative coalitions become less consequential for the substance of decisions. The tension between fair representation and clear responsibility does not disappear under the separation of powers.

Yet presidential government also opens up new trade-offs. It achieves the separation of powers by concentrating much executive power in a single human being. This is to some extent a historical overhang from monarchy (Colomer, 2013; DiClerico, 1987, p. 304; Nelson, 2014; Scheuerman, 2005) and it tends to weaken the programmatic capacities and voting discipline of political parties (Carey, 2007; Samuels \& Shugart, 2010). Furthermore, when presidential constitutions try to limit the power of the president it often leads to further tradeoffs. For example, term limits for presidents eliminate (personal) electoral accountability in the presidents' last term and make it impossible to re-elect well-performing incumbents. To reduce the institutional dominance of a fixed-term president, presidential constitutions typically disallow the dissolution of the assembly, thereby removing a way to resolve a deadlock between the executive and the legislature. A number of studies suggest that presidential systems increase the risk that democratically elected governments subvert democracy once they are in office (Maeda, 2010; Pérez-Liñán, Schmidt, \& Vairo, 2019; Svolik, 2015).

All of this raises the question whether the optimization potential of presidential systems could not also be achieved differently. Some might see semipresidentialism as desirable, but this hybrid between parliamentarism and presidentialism might just as well lead to the worst of both worlds. After all, a semi-presidential system is most commonly defined by having a directly elected president and a prime minister who can be dismissed in a no-confidence vote of the assembly (Elgie, 2011). Hence to the extent that the president is powerful, these systems also suffer from the problems associated with the institutionalized personalization of the executive (Åberg \& Sedelius, 2018; Samuels \& Shugart, 2010).
And since the parliament is not liberated from keeping the prime minister and his or her cabinet in office, issuespecific majority formation is just as difficult as under pure parliamentarism.

\section{Semi-Parliamentarism as Optimization}

Is there another form of the separation of powers that has the same optimization potential as presidential government, but avoids institutionalized personalism in the executive? Ganghof (2018) argues that "semiparliamentary" government is a candidate. Its trick, as it were, is to move the locus of the separation of powers into the legislature. Semi-parliamentary systems divide the legislature into two parts, both of which are directly elected but only one of which can dismiss the prime minister in a no-confidence vote. They thus separate power between one part of the legislature that is fused with the executive and another part that is not.

Existing semi-parliamentary systems are essentially a special form of bicameralism. They include the Australian Commonwealth and Japan as well as the Australian states of New South Wales (NSW), South Australia, Tasmania, Victoria and Western Australia (Smith, 2018; Taflaga, 2018). These systems are special because upper houses in otherwise parliamentary systems are typically either not directly elected (like the German Bundesrat) or, if they are, they also possess the right to a noconfidence vote (like the Italian Senate).

Ganghof (2018) argues that semi-parliamentary systems have the same optimization potential as presidential systems because the electoral systems of the two parts of the legislature can also be designed differently. The first, "confidence," chamber can construct two-party systems and one-party majority cabinets, whereas the second, "legislative," chamber can allow for multidimensional, multiparty competition. Hence voters can clearly authorize a party and its prospective prime minister to form the government, which is stabilized by a clear majority in the first chamber. Executive power is not as personalized as in a presidential system, because the prime minister can be replaced at any time by the majority party or the first chamber majority. However, this party cannot govern alone but has to seek issue-specific majority support in the more proportionally elected second chamber. Ganghof et al. (2018) show that well-designed semi-parliamentary systems can achieve a position in the upper right quadrant of Figure 1. That is, they can achieve identifiable and stable one-party cabinets, governing with issue-specific multi-party coalitions in a multidimensional space.

Consider the Australian state of Victoria as an example. After the 2018 election of both chambers, the Labor party governs with a large majority in the first chamber (62.5 percent of all seats). In the second chamber, however, the government is in a minority position (45 percent). The balance of power is held by eight (!) minor parties, only one of which (the Greens) also gained seats in 
the first chamber (Victorian Electoral Commission, n.d.). Victorian governments seek issue-specific support in the second chamber, which allows all opposition parties to become members of legislative coalitions. Yet since the government can choose between different coalitions, it does not necessarily have to make many large concessions (cf. Tsebelis, 2002).

While all existing semi-parliamentary systems are bicameral, Ganghof $(2016,2018)$ suggests that this is no necessity. The confidence chamber could also be turned into a two-party confidence committee embedded in a proportionally elected parliament. Consider, e.g., a mixed-member proportional electoral system as it is used in Germany and New Zealand, in which part of parliament is elected in single-member districts, but the overall composition of parliament is proportional. A semi-parliamentary system could be created by restricting the right to participate in the no-confidence procedure to the members elected in single-member districts. Smaller parties would thus be fairly represented in the legislative process but denied power over the government-just as in Victoria and other bicameral forms of semi-parliamentarism.

A question to ask about semi-parliamentarism, and presidentialism for that matter, is whether the optimization achieved by having two elected agents of voters may not lead to new trade-offs elsewhere in the system. Most notably, the question is whether the separation of powers does not lead to a massive problem of legislative deadlock.

\section{The Problem of Deadlock}

The problem of deadlock has played a central role in the political science debate about presidentialism following the famous work of Juan Linz (1990). This literature has shown, however, that the problem can easily be exaggerated (Chaisty, Cheeseman, \& Power, 2018; Cheibub, Przeworski, \& Saiegh, 2004). In this section, I discuss some potential institutional remedies for the problem of deadlock. I also suggest that this problem is more difficult to solve in presidential systems because some remedies might reinforce the concentration of power in a single human being.

First, assembly dissolution and early elections can resolve deadlock (Bulmer, 2017). Presidential government is often associated with the impossibility of assembly dissolution, but there are presidential constitutions that allow dissolution under certain circumstances (Cheibub, Elkins, \& Ginsburg, 2014). As noted above, however, if the president is given the power to dissolve the legislature, this may strengthen the personalist concentration of power in the executive. Dissolution power has been identified as an important component of authoritarian forms of presidential supremacy (Stykow, 2019).

The possibility of assembly dissolution might be more compatible with the semi-parliamentary variant of the separation of powers, especially when it requires a double dissolution of both houses. More than half of the existing semi-parliamentary constitutions allow for a double dissolution of (parts of) both houses under certain circumstances (Australian Commonwealth, NSW, South Australia and Victoria). In Victoria, for example, the terms of the second chamber are tied to the first chamber. Hence whenever the first chamber is dissolved-either because of a "deadlocked bill" or after a successful no-confidence vote-the entire second chamber is dissolved too (Taylor, 2006, Articles 6A and $65 \mathrm{E}(2)$ in combination with Article $28(2)$ of the Constitution of Victoria). This dissolution-option for resolving deadlock does not give up on the separation of powers entirely, because the government or the first chamber majority can never dissolve the second chamber without standing for re-election themselves.

Second, a possible way to reduce the likelihood of deadlock is to deny one of the two "branches" absolute veto power. Some presidential systems allow the assembly to override the president's veto with a simple or absolute majority, rather than a supermajority (Colomer \& Negretto, 2005, p. 85). In bicameral systems, the common approach is to weaken the veto power of the second chamber. In a semi-parliamentary system, however, it might also be plausible-in analogy to presidents with weak veto powers in presidential systems - to weaken the veto power of the first chamber. If we see the first chamber mainly as a way for voters to directly choose a non-personalized (single-party) minority cabinet, it might not necessarily require absolute legislative veto power. After all, minority cabinets in parliamentary systems have no legislative veto power either. To be able to govern, however, the government and/or its majority in the first chamber would probably need strong agenda-setting powers vis-à-vis the second chamber, such as the double dissolution threat or institutional privileges in the initiation and amendment of (certain types of) legislation.

Third, another way to resolve deadlock in a separation of powers-system could be to let the voters decide. Early elections do this as well, but rather bluntly. A complementary and issue-specific resolution mechanism is a popular referendum on a deadlocked bill. In NSW, a popular referendum, initiated by the first chamber, is the only way to resolve bicameral deadlock on a particular bill (Art. 5B of the Constitution of NSW). While the rules in NSW privilege the first chamber as the agenda setter, it might be desirable to allow both chambers to initiate a referendum on a deadlocked proposal. This would tend to give greater bargaining strength to whichever chamber's position is deemed closer to the preferences of the voters. Moreover, given the inherent uncertainty of a referendum, both chambers would probably have strong incentives to compromise and thus avoid the referendum.

\section{Conclusion}

The constitutional separation of powers between the executive and the legislature is often understood as 
a way to limit and diffuse power or as a particular approach to controlling voters' representative "agents" (e.g., Strøm, 2003). Here I have adopted a somewhat different, complementary, perspective. This separation can also be understood as an effort to balance competing goals in the constitutional design of democracy. My point has not been that the resulting balance is better, all things considered, than that achievable under parliamentary government. It might be, but I don't think we have enough evidence to support such a claim. My point is rather that the separation of powers allows for a type of balance that is unavailable under pure parliamentarism. In particular, parliamentary government makes it extremely difficult to reconcile the goals of identifiability and cabinet stability with the goal of issue-specific decision-making in a multidimensional space. Presidential and semi-parliamentary government can reconcile these goals to some extent because the executive can be designed to emerge and survive independently from a multi-party legislature. It is either elected by the people (presidentialism) or emerges from a separated part of the legislature, in which the effective number of parties is low (Australian-style semiparliamentarism).

What I did suggest, at least tentatively, is that the semi-parliamentary version of the separation of powers is superior to the presidential version. While more theoretical and empirical analysis is needed to substantiate this suggestion, it might serve as a reminder that democratic constitutions resulted from a path-dependent process that was strongly influenced by the self-interest of powerful actors, as well as by their limited foresight (e.g., about the emergence of political parties). Hence there is no reason to assume that the constitutional designs that dominate the democratic world today, such as presidential government, could not be improved upon. The frequent tendency to equate the notion of the separation of powers with presidential government might to some extent be justified historically, but it is not justified logically. The search for more optimal democratic constitutions should certainly continue.

\section{Acknowledgments}

I would like to thank Sebastian Eppner, Bonnie N. Field, Alexander Pörschke and Petra Stykow for helpful comments and suggestions.

\section{Conflict of Interests}

The author declares no conflict of interests.

\section{References}

Åberg, J., \& Sedelius, T. (2018). A structured review of semi-presidential studies: Debates, results and missing pieces. British Journal of Political Science, 2018, 1-26. https://doi.org/10.1017/S0007123418000017
Angelova, M., Bäck, H., Müller, W. C., \& Strobl, D. (2018). Veto player theory and reform making in Western Europe. European Journal of Political Research, 57(2), 282-307.

Bergman, T. (1993). Formation rules and minority governments. European Journal of Political Research, 23(1), 55-66.

Best, R. E., \& Zhirnov, A. (2015). The perils and pitfalls of ignoring disproportionality's behavioral components. Electoral Studies, 40, 256-267. https://doi. org/10.1016/j.electstud.2015.09.010

Bulmer, E. (2017). Dissolution of parliament: International IDEA constitution-building primer 16 ( $2 \mathrm{nd}$ ed.). Stockholm: International Institute for Democracy and Electoral Assistance.

Carey, J. M. (2007). Competing principals, political institutions, and party unity in legislative voting. American Journal of Political Science, 51(1), 92-107.

Carey, J. M., \& Hix, S. (2011). The electoral sweet spot: Low-magnitude proportional electoral systems. American Journal of Political Science, 55(2), 383-397.

Chaisty, P., Cheeseman, N., \& Power, T. J. (2018). Coalitional presidentialism in comparative perspective: Minority presidents in multiparty systems. Oxford: Oxford University Press.

Cheibub, J. A. (2006). Presidentialism, electoral identifiability, and budget balances in democratic systems. American Political Science Review, 100(3), 353-368.

Cheibub, J. A. (2007). Presidentialism, parliamentarism, and democracy. New York, NY: Cambridge University Press.

Cheibub, J. A., Elkins, Z., \& Ginsburg, T. (2014). Beyond presidentialism and parliamentarism. British Journal of Political Science, 44(3), 515-544.

Cheibub, J. A., Martin, S., \& Rasch, B. E. (2019). Investiture rules and formation of minority governments in European parliamentary democracies. Party Politics, 2019. https://doi.org/10.1177/1354068819850447

Cheibub, J. A., Przeworski, A., \& Saiegh, S. M. (2004). Government coalitions and legislative success under presidentialism and parliamentarism. British Journal of Political Science, 34(4), 565-587.

Colomer, J. M. (2013). Elected kings with the name of presidents: On the origins of presidentialism in the United States and Latin America. Revista Lationamericana de Politica Comparada, 7, 79-97.

Colomer, J. M., \& Negretto, G. L. (2005). Can presidentialism work like parliamentarism? Government and Opposition, 40(1), 60-89.

DiClerico, R. E. (1987). James Wilson's presidency. Presidential Studies Quarterly, 17(2), 301-317.

Elgie, R. (2011). Semi-presidentialism: Sub-types and democratic performance. Oxford: Oxford University Press.

Field, B. N. (2016). Why minority governments work: Multilevel territorial politics in Spain. New York, NY: Palgrave Macmillan.

Field, B. N. (2019, July 20). Is something wrong with 
Spain's political leaders? Monkey Cage. Retrieved from https://www.washingtonpost.com/politics/ 2019/07/20/is-something-wrong-with-spainspolitical-leaders

Ganghof, S. (2015). Four visions of democracy: Powell's elections as instruments of democracy and beyond. Political Studies Review, 13(1), 69-79.

Ganghof, S. (2016). Combining proportional and majoritarian democracy: An institutional design proposal. Research \& Politics, 3(3), 1-7. https://doi.org/10. $1177 / 2053168016665640$

Ganghof, S. (2018). A new political system model: Semiparliamentary government. European Journal of Political Research, 57(2), 261-281. https://doi.org/10. 1111/1475-6765.12224

Ganghof, S., \& Eppner, S. (2019). Patterns of accountability and representation: Why the executive-parties dimension cannot explain democratic performance. Politics, 39(1), 113-130.

Ganghof, S., Eppner, S., \& Heeß, K. (2015). Normative balance and electoral reform: A Finnish puzzle and a comparative analysis. West European Politics, 38(1), 53-72.

Ganghof, S., Eppner, S., \& Pörschke, A. (2018). Australian bicameralism as semi-parliamentarism: Patterns of majority formation in 29 democracies. Australian Journal of Political Science, 53(2), 211-233.

Ganghof, S., Eppner, S., Stecker, C., Heeß, K., \& Schukraft, S. (2019). Do minority cabinets govern more flexibly and inclusively? Evidence from Germany. German Politics, 28(4), 1-21. https://doi.org/10.1080/ 09644008.2019 .1635120

Klüver, H., \& Zubek, R. (2018). Minority governments and legislative reliability: Evidence from Denmark and Sweden. Party Politics, 24(6), 719-730.

Lijphart, A. (2012). Patterns of democracy: Government forms and performance in thirty-six countries. New Haven, CT: Yale University Press.

Linz, J. J. (1990). The perils of presidentialism. Journal of Democracy, 1(1), 51-69.

Maeda, K. (2010). Two modes of democratic breakdown: A competing risks analysis of democratic durability. The Journal of Politics, 72(4), 1129-1143.

Mainwaring, S., \& Shugart, M. S. (1997). Juan Linz, presidentialism, and democracy. Comparative Politics, 29(4), 449-471.

McGann, A. J. (2013). Fairness and bias in electoral systems. In J. H. Nagel \& R. M. Smith (Eds.), Representation: Elections and beyond (pp. 90-113). Philadelphia, PA: University of Pennsylvania Press.

Nelson, E. (2014). The royalist revolution: Monarchy and the American founding. Harvard: Harvard University Press.

Pérez-Liñán, A., Schmidt, N., \& Vairo, D. (2019). Presidential hegemony and democratic backsliding in Latin America, 1925-2016. Democratization, 26(4), 606-625.

Powell, B. G. (2000). Elections as instruments of democ- racy: Majoritarian and proportional visions. New Haven, CT: Yale University Press.

Raabe, J., \& Linhart, E. (2018). Which electoral systems succeed at providing proportionality and concentration? Promising designs and risky tools. European Political Science Review, 10(2), 167-190.

Reinermann, H., \& Barbet, B. (2019). Party system dimensionality and perceived quality of representation. Party Politics, 2019. https://doi.org/10.1177/ 1354068818823687

Rosset, J., \& Stecker, C. (2019). How well are citizens represented by their governments? Issue congruence and inequality in Europe. European Political Science Review, 11(2), 145-160. https://doi.org/10.1017/ S1755773919000043

Samuels, D., \& Shugart, M. (2010). Presidents, parties, and prime ministers: How the separation of powers affects party organization and behavior. Cambridge: Cambridge University Press.

Scheuerman, W. E. (2005). American kingship? Monarchical origins of modern presidentialism. Polity, 37(1), 24-53.

Shugart, M. S. (2001). Electoral "efficiency" and the move to mixed-member systems. Electoral Studies, 20(2), 173-193.

Shugart, M. S., \& Carey, J. M. (1992). Presidents and assemblies: Constitutional design and electoral dynamics. New York, NY: Cambridge University Press.

Sieberer, U. (2015). Hire or fire? The link between cabinet investiture and removal in parliamentary democracies. In B. E. Rasch, S. Martin, \& J. A. Cheibub (Eds.), Parliaments and government formation: Unpacking investiture rules (pp. 309-330). Oxford: Oxford University Press.

Smith, R. (2018). New South Wales: An accidental case of semi-parliamentarism? Australian Journal of Political Science, 53(2), 256-263.

Stecker, C., \& Tausendpfund, M. (2016). Multidimensional government-citizen congruence and satisfaction with democracy. European Journal of Political Research, 55(3), 492-511.

Strøm, K. (2003). Parliamentary democracy and delegation. In K. Strøm, W. C. Müller, \& T. Bergman (Eds.), Delegation and accountability in parliamentary democracies (pp. 55-106). Oxford: Oxford University Press.

St-Vincent, S. L., Blais, A., \& Pilet, J.-B. (2016). The electoral sweet spot in the lab. Journal of Experimental Political Science, 3(1), 75-83.

Stykow, P. (2019). The devil in the details: Constitutional regime types in post-Soviet Eurasia. Post-Soviet Affairs, 35(2), 122-139.

Svolik, M. W. (2015). Which democracies will last? Coups, incumbent takeovers, and the dynamic of democratic consolidation. British Journal of Political Science, 45(4), 715-738.

Taflaga, M. (2018). What's in a name? Semiparliamentarism and Australian Commonwealth 
executive-legislative relations. Australian Journal of Political Science, 53(2), 248-255.

Taylor, G. (2006). The constitution of Victoria. Sydney: The Federation Press.

Tsebelis, G. (2002). Veto players: How political institutions work. Princeton, NJ: Princeton University Press. Victorian Electoral Commission. (n.d.). State election
2018 results. Victorian Electoral Commission. Retrieved from https://www.vec.vic.gov.au/Results/ State2018/Summary.html

Ward, H., \& Weale, A. (2010). Is rule by majorities special? Political Studies, 58(1), 26-46.

Weale, A. (2019). Three types of majority rule. The Political Quarterly, 90, 62-76.

\section{About the Author}

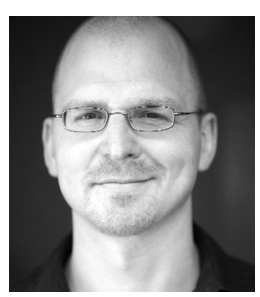

Steffen Ganghof is Professor of Comparative Politics at the University of Potsdam. His research focuses on democratic theory and political institutions. He has recently published (in German) a monograph on research design in political science (Forschungsdesign in der Politikwissenschaft. Eine theorieorientierte Perspektive mit Anwendungsbeispielen, Springer, 2019). His research articles have appeared in journals such as the British Journal of Political Science, Comparative Political Studies and the European Journal of Political Research. 


\section{Appendix}

\section{Measurement of Simple and Complex Majoritarianism (see Figure 1)}

\subsection{Simple Majoritarianism}

\subsubsection{Identifiability}

Average of Blocvote and Linkage

Blocvote $=$ Share of votes of the two biggest blocs (a bloc being a party or a pre-electoral coalition of parties)

Linkage $=$ Average of Pecgov and a majority status (dummy)

Pecgov $=$ Dummy that is 1 for each cabinet that consists of a bloc

\subsubsection{Clarity of Responsibility}

Duration-weighted average of cabinet types, based on the following ranking:

$1=$ Single-party with majority in all directly elected houses

.85 = Single-party with majority in lower house only

$.66=$ Multi-party with majority in all directly elected houses

$.50=$ Multi-party with majority in lower house only

$.33=$ Single-party minority

$0=$ Multi-party minority

\subsubsection{Cabinet Stability}

Average duration of cabinets. The average duration of cabinets is calculated for each legislative term and divided by the constitutionally maximal term length. Those durations are then averaged (weighted by the term length). A new cabinet begins when elections take place or the party composition of the cabinet changes.

\subsection{Complex Majoritarianism}

\subsubsection{Mechanical Proportionality}

Log of effective district magnitude (Taagepera \& Shugart, 1989)

$M=(50 / T)$, with $M$ being the effective district magnitude and $T$ the legal threshold. In countries with directly elected upper houses, values are for the house with the greater proportionality.

\subsubsection{Unconstrained Multidimensionality of Representation}

Effective number of dimensions (END) based on the results of principal component analyses that use party positions on several items as variables and parties as cases. Cases are weighted with seat shares.

$$
\mathrm{END}=\frac{1}{\sum \mathrm{P}_{i}^{2}}
$$

with $i$ components and $p$ being a component's share of explained variance (the relative size of the Eigenvalue). In countries with directly elected upper houses, values are for the house with higher dimensionality.

\subsubsection{Issue-Specificity in Legislative Coalition-Building}

Duration-weighted average of cabinet types, based on the following ranking:

$0=$ Majority cabinet

$.5=$ Formal minority cabinet

$1=$ Substantial minority cabinet

In countries with directly elected upper houses, the values are for the house with the greater potential for issue-specific coalition-building.

\section{Reference:}

Taagepera, R., \& Shugart, M. S. (1989). Seats and votes: The effects and determinants of electoral systems. New Haven, CT: Yale University Press. 